\title{
Flexible Work Practices (FWP) - An effective instrument in the retention of talent: A survey of selected JSE-listed companies
}

\author{
P.A. Grobler* and A.J. de Bruyn \\ Department of Human Resource Management (Academic), \\ School of Management Sciences, UNISA, PO Box 392, \\ Pretoria 0003, Republic of South Africa \\ groblpa@unisa.ac.za
}

Received November 2010

\begin{abstract}
There is a paucity of research available on the use of flexible work practices (FWP) in South African companies. The primary aim of this study was to close this gap by determining to what extent listed companies on the JSE in the very important sectors of Finance, Telecommunications and Technology make use of these practices. A secondary aim was to establish whether companies perceived any advantages, disadvantages, barriers and solutions when implementing or thinking to implement these practices. Although neither disadvantages nor barriers were found, significant differences between the usage of these practices and some corpographic variables such as the size of staff, nature of competition and the business unit strategies followed, were found. It also became clear that although these practices were available within companies, the percentage of staff making use of them were very small. However, a number of advantages regarding the use of these practices were identified by companies, as well as a number of solutions to successfully implement these practices in companies. The study concludes that companies should seriously consider expanding the use of these practices as numerous benefits exist for the company, the employee and the larger community.
\end{abstract}

*To whom all correspondence should be addressed.

\section{Introduction}

One of the primary challenges facing managers today is to find methods of reducing employee turnover - especially the turnover of skilled/talented employees (Ready \& Conger, 2007:69-77; Meisinger, 2007:12; Robert \& Börjesson, 2006: 521-549). These employees play a leading role in organisations. Normally a large amount of money and many hours are invested in their training and development. In the past, companies placed a great deal of emphasis on issues such as a neat and safe working environment, job enrichment, good communication, financial incentives, praise and recognition (MacKay, 2007:29; Döckel, Basson \& Coetzee, 2006:21). However, it has become apparent that this is not sufficient, particularly for generation $\mathrm{X}$ and $\mathrm{Y}$ employees, who are now a major part of the workforce (Horgan, 2008:1). Thus, other strategies need to be devised to motivate and retain employees, such as flexible work practices (FWP), also known as flexible work arrangements (FWA) (Kelly \& Kalev, 2006: 380). This concept has recently become interwoven with concepts such as work-life balance, family-friendly practices, workplace equity, worklife policies and alternative work patterns (O'Brien \& Hayden, 2008:199). A number of reasons can be advanced for this new strategy:

- Companies have recognised that if they need to undertake major retrenchments they will not be able to obtain the lost talent with the next economic upswing (Harris, 2009:16).

- The cost of retraining new employees is enormous and retraining is time consuming (Cheese, 2008: 38-42).

- The strategy plays a vital role in the retention of talented employees (Meisinger, 2007:12; Harris 2007:32; Döckel, et al., 2006:20).

- The new approach helps to establish companies as an employer of choice (Kelliher \& Anderson, 2008:419431; O’Brien \& Hayden, 2008:199-228).

Countries and businesses (both large and small) are now engaged in a war for talent (Frase, 2007:67). They have found that, in order to survive, they must not only obtain the best talent available anywhere in the world but once they have obtained the best talent they must make every endeavour to retain it (Taleo Corporation Research, 2008:14). This also applies to South Africa as explained by Richard Nefdt, Chief Executive Officer of Reality Check: "Retaining skilled employees should be a priority for South African businesses to ensure that they survive the downturn" (Harris, 2009:16).

In the latest crisis, major companies in the world such as Citigroup, IBM, KPMG, UBS, Honda, Lloyds TBS, Unilever, British Telecom, ArcelorMittal, and in South 
Africa, British American Tobacco SA, Accenture, Nedbank and Citrix Systems South Africa, to mention but a few, have started to formally introduce the concept of flexible work practices (FWP) into their organisations as part of their human resource management system (Sunday Times/Careers, 2009; Knowledge Resources, 2009; Beeld (Sake) 2009; Sexton, 2008:1).

There is no doubt that the present worldwide economic crisis will have a major impact on the way in which companies will be managing their workforces in future (Sunday Times/Careers 2009). In facing this new dilemma, companies are making innovative adjustments to their overall business strategies, such as introducing flexible work practices to ensure they survive and remain competitive in their industries (Harris, 2009: 16).

\section{The South African scenario}

For some years South Africa had been experiencing serious losses of skilled people in a number of critical industries, such as the financial sector, telecommunications and technology. This process has become known as the "brain drain" (Beeld Sake 24, 2009:12). These sectors can be seen as important building blocks in the development of any country (South Africa. The Presidency, 2008:3-80; Eigenhuis \& Van Dijk, 2007; Jansen, Steenbakkers \& Jägers, 2007). Although there are a number of reasons for these losses, the important factor appears to be the working environment (Esterhuizen \& Martins, 2008).

According to the World Competitiveness Report 2008/2009 (World Economic Forum, 2009:10), of the 134 countries participating in the project, South Africa obtained an overall rating of 45 out of 134 . This can be regarded as an outstanding rating because South Africa remains the highest ranked country in Sub-Saharan Africa and continues to receive excellent results in complex areas such as the availability of the latest technology (37th), innovation (37th), the quality of private institutions (25th), financial efficiency (24th), and business sophistication (33rd) (World Economic Forum, 2009:303). However, a number of negative factors pertaining to the workplace also exist, such as labour market flexibility (88th), hiring and firing practices (129th) and labour-employer relations (119th). As the competition for talent among countries and rival companies increases, our advantage in the industries mentioned earlier is under threat. Hence, devising management strategies such as flexible work practices to prevent further losses of skilled staff in these sectors is vital for the future development of South Africa and requires immediate attention.

\section{Aims of the study}

In view of the important role played by flexible work practices in the retention of skilled staff as suggested by the above discussion, the aim of this study is to achieve the following objectives:
- $\quad$ to provide an overview of flexible work practices

- to empirically assess the extent to which these practices are utilised in the financial, telecommunications and technology sectors in South Africa

- $\quad$ to establish the perceptions of companies regarding the advantages and disadvantages when implementing or thinking of implementing flexible work practices and

- $\quad$ to establish the potential barriers and possible solutions to successfully implementing flexible work practices

\section{Value of the study}

Despite the heightened interest in research in this area internationally, not much has been published locally, which means that South Africa is lagging behind (Odendaal \& Roodt, 2002:76, Hloma \& Ortlepp, 2006:30). As no empirical research exists with regard to FWP in the general industrial sector of South Africa, this study aims to contribute important knowledge in this area. It will enable companies to overcome barriers in this regard, and to successfully implement these practices in their organisations.

\section{Flexible work practices (FWP) theory}

\section{FWP defined}

According to a literature review, the concept generally refers to greater flexibility in the workplace (Mathis \& Jackson, 2003:86-87; Price, 2004:198-202; Stredwick, 2005:211-233; Gilmore \& Williams, 2009:354-355). The BNET business dictionary defines FWP as follows: "it is a generic term for employment practices that differ from the traditional norm in terms of hours worked, the length of a contract or the place of work". Mullins (2007:804) sees it as "a range of flexible working practices designed to help employees balance work and home life". One can safely state that FWPs enable both the employee and the supervisor to customise work schedules, work arrangements and responsibilities to accommodate family responsibilities, other personal circumstances and the employer.

\section{Types of FWP}

Although initially seen in the 1960 s as a concept that includes activities such as shift work, overtime, part-time and temporary work, it soon evolved to include activities such as flexitime, a compressed work week, telecommuting and virtual working. These practices originated from the cost-cutting strategies pursued by companies, the entry of women into the job market and the rapid development of technology (Ministry of Manpower Singapore, 2001:1-33).

Table 1 provides a classification and brief description of FWPs found in companies/organisations today. 
Table 1: Classification of flexible work practices

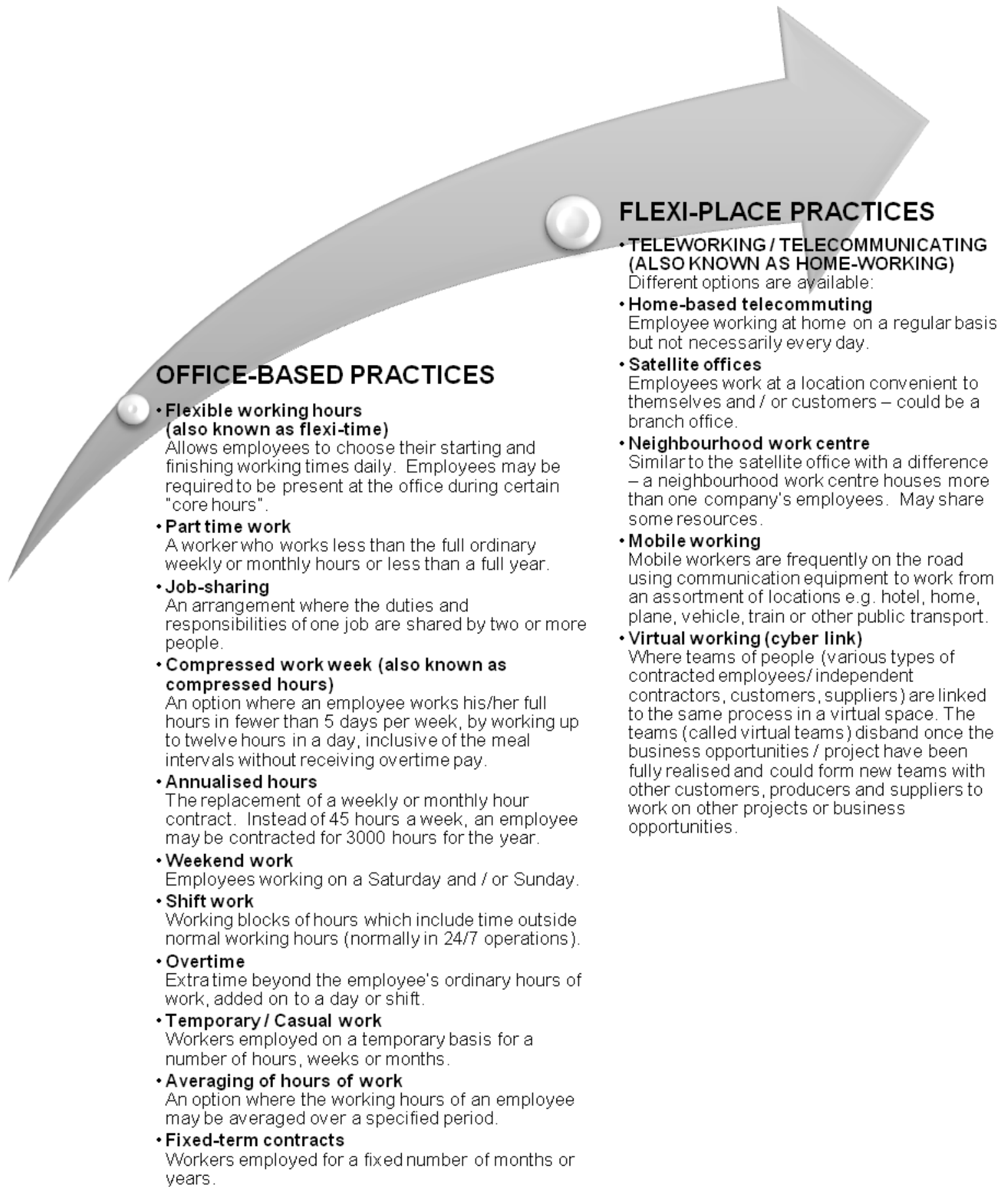

Source: Adapted from O’Brien \& Hayden (2008:227); Ministry of Manpower Singapore (2001:1-23).

\section{Reasons for FWP}

There is no doubt that the increasing use of flexible work practices worldwide can be attributed largely to two factors. Firstly, the nature of the workforce has changed. It has become more diverse, for example, with more single working parents than ever before requiring a balance between work and home. Secondly, the current business environment in which companies find themselves is extremely turbulent (Davis et al., 2007:32-37). In the present economic climate, for example, companies are asking their employees whether they would like to move to a four-day working week and accept a $20 \%$ pay cut by temporarily changing their conditions of service (Sunday Times/Careers, 2009). In this way, a company can cut its costs in an effort to improve performance on existing capital while still retaining its talented/skilled employees.

\section{Benefits of FWP}

Implementing these practices has benefits not only for the employer but also for the employees and the community at large (Mullins, 2007:620-621). Table 2 summarises the benefits that emerged from numerous studies on different types and sizes of organisation. 
Table 2: Benefits of implementing flexible work practices for the employer, the employee and the community at large

\begin{tabular}{|c|c|}
\hline EMPLOYER & $\begin{array}{l}\text { - } \text { increased competitive advantage due to higher productivity and } \\
\text { - } \text { enew staff problems } \\
\text { - } \text { maximum use of facilities and equipment } \\
\text { - } \text { round the clkock custoimer service } \\
\text { - } \text { access to global expertise } \\
\text { - cost savings e.g. office space } \\
\text { the "settling in" period may be less disruptive when employees } \\
\text { - } \text { arrive at different times } \\
\text { - } \text { supports pooling of ideas } \\
\text { staffing levels can be varied to meet fluctuations in products and }\end{array}$ \\
\hline EMPLOYEE & $\begin{array}{l}\text { - } \quad \text { improved morale } \\
\text { - } \quad \text { higher producytivity } \\
\text { - } \text { decreased employee tardiness and unscheduled absences } \\
\text { - } \quad \text { less stress commuting to the office in peak traffic times } \\
\text { - } \quad \text { improve quality of working life } \\
\text { - } \quad \text { employees will feel more empowered }\end{array}$ \\
\hline COMUNITY & $\begin{array}{l}\text { - } \text { reduced traffic and [pollution (possible Carbon credits and } \\
\text { participation in Clean Development mechanisms) } \\
\text { - } \text { employment opportunities for the disabled } \\
\text { - } \quad \text { incre prosperity in rural area } \\
\text { incring sense of community focus }\end{array}$ \\
\hline
\end{tabular}

Source: Adapted from Meisinger (2007:12); Harris (2007:33); Döckel et al. (2006: 20-22); Sandler (2008:10-11); Sandler (2006:S1-S4); Wilson (2007:1); Roberts (2005:1); Kettleborough (2009:6); Shyrme (2002:1-4); O’Brien \& Hayden (2008:19); Stredwick \&Ellis (2008:30)

\section{Problems/Challenges facing companies in implementing FWP}

Although a number of benefits do emanate from implementing these practices, there are a number of problems/challenges that companies need to note. Table 3 indicates a few of these problems/challenges, as identified in the literature.

Despite the drawbacks indicated in Table 3, the popularity of these practices among employees and companies globally cannot be ignored, as explained by Galinsky, Bond and Hill (2004:21), who state that "in a nationally representative sample surveyed in 2002, $79 \%$ of US workers report that they would 'like to have more flexible work options' and $61 \%$ would prefer to reduce their working hours". According to Meisinger (2007:12), "an increasing number of organisations offer employees non-traditional scheduling options". The application of these practices as part of the formal human resource management processes can therefore not be ignored. How would a company/organisation go about implementing such practices and eliminate the problems/challenges indicated earlier?

\section{Implementing FWP successfully}

Implementing flexible work practices successfully within any organisation is a complex, dynamic and challenging process. For managers, their staff and the organisation to cope, certain guidelines need to be available and to be followed. The ultimate result should be a stable new environment which incorporates the desired changes. A model designed by Robert A Paton and James McCalman suits this need perfectly (Paton \& McCalman, 2008:108). The model, which is known as the Intervention Strategy Model (ISM), consists of a number of steps: problem initialisation, the definition phase, the evaluation phase, the implementation phase, feedback, problem conclusion and an environmental development loop (see Figure I). 
Table 3: Problems/challenges facing companies in implementing flexible work practices

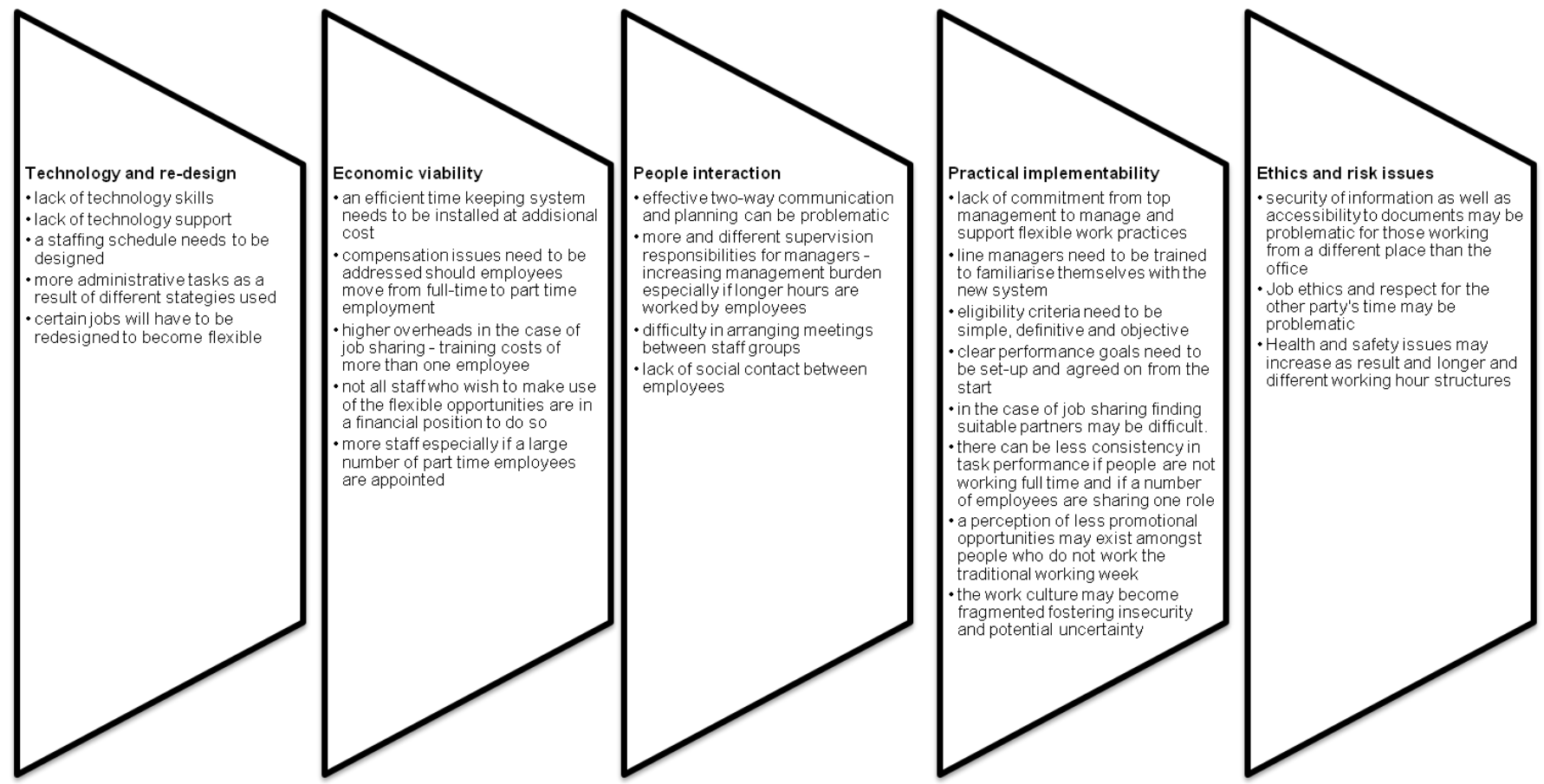

Source: Adapted from O’Brien \& Hayden (2008:225); Kelly \& Kalev (2006: 379-416t); Kettleborough (2009:4); Ministry of Manpower Singapore (2001:1-23)

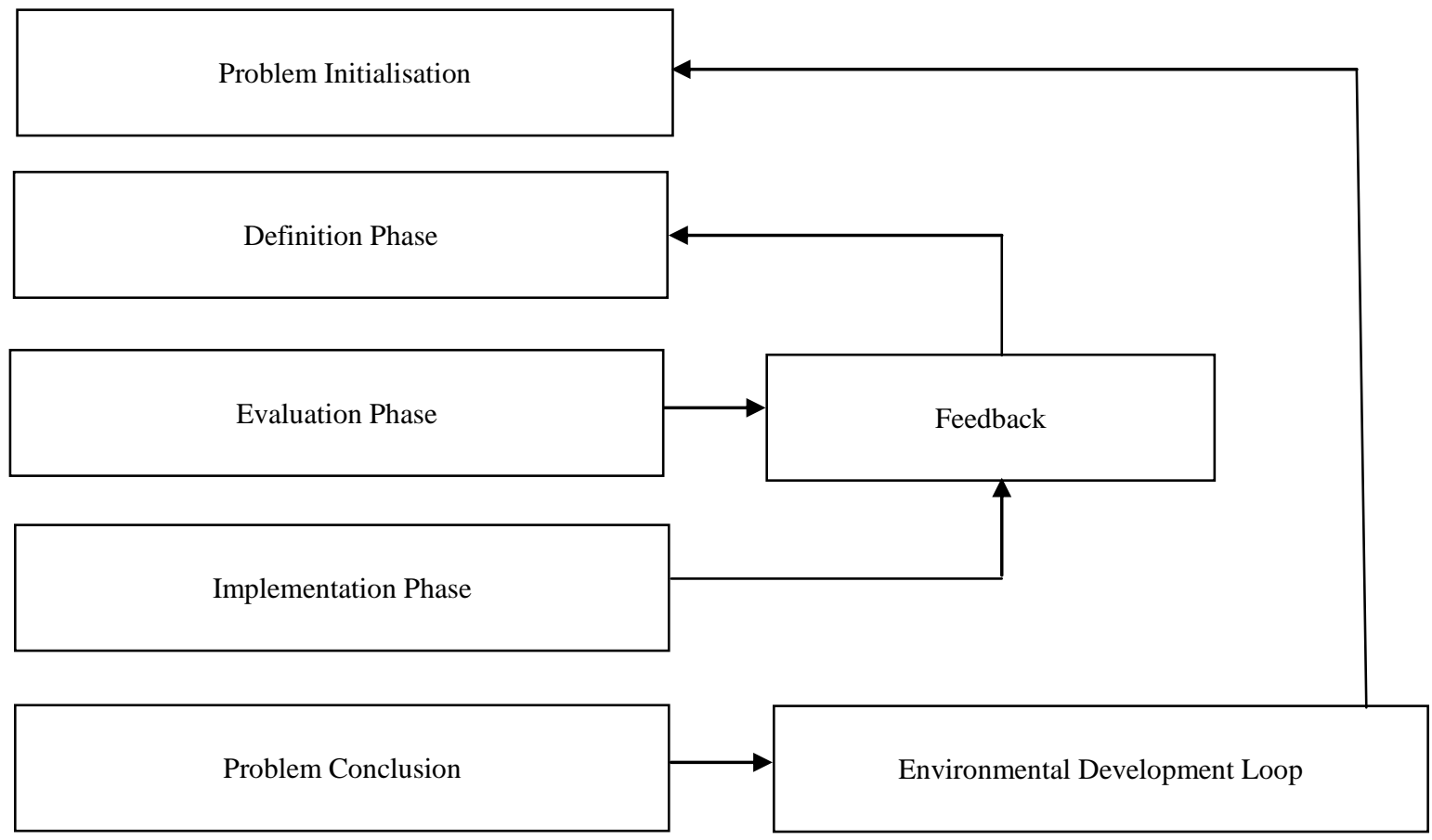

Source: Paton \& McCalman 2008:108.

Figure 1: The basic phases of the Intervention Strategy Model (ISM) 
The model is seen as valuable as it is interactive and integrative and at each step permits both exchange of data and feedback. The model can also be used in both the private and the public sectors. The individual steps in the model will be discussed briefly from the perspective of flexible work practices (Paton \& McCalman, 2008:108120).

\section{- Problem initialisation}

In this step the company identifies the need to implement FWP. Issues that might initiate such a move could include: the loss of talented staff, increasing competition from competitors and the worldwide financial crisis. Having identified the need to implement FWP, a project team consisting of all stakeholders such as line managers, employees, the computer division and unions, will need to be assembled. This group will be known as change agents. The team will be responsible for handling the transition from the old to the new. It is important that the support of top management should be obtained. Initial communication to the staff about the new project is also vital.

\section{- Definition phase}

This phase entails an in-depth study of the change situation from both a historical and a futuristic perspective. The project team will meet regularly to discuss issues such as the impact of FWP on the culture of the organisation, its systems and possible difficulties in future, and who will participate, for example, which division or level of staff in the company. Depending on the type of system to be used, the traditional nine-to-five working arrangement will change when FWP are introduced. Other matters to receive attention at this stage will be: the formulation of objectives, for example, what is to be achieved, the success criteria, for example, how is success to be measured (cost savings, productivity increase) and the identification of constraints, for example, available resources (people, equipment, money).

\section{- Evaluation phase}

This phase generates and evaluates the potential solution options. The project team identifies the different types of FWP that could possibly be used by the company. Different options could be generated by means of brainstorming, the Delphi-method, interviews, focus groups or structured meetings. Once a number of options have been identified, they must be evaluated. This process can take place by means of computer simulations or network analysis. Issues to be considered here are: can the company afford it, is there time to train the staff (supervisors and employees), has the process been fully communicated and is it understood by the staff. If any problems arise during this phase, the matter can be referred back to the definition phase (see Figure I).

\section{- Implementation phase}

If all goes well in the previous step, the foundation of an achievable strategy to deal with the change will have been laid. At this stage, the objectives will be clear, the options selected and the systems well defined. All that remains is to package the outcomes into a coherent whole and introduce the system. According to Kettleborough (2009:6), the issues to be addressed here in respect of FWP include the following:

- Ensuring that an effective monitoring system is in place before the FWP are implemented.

- Having a well-developed human resource information system (HRIS) in place which will enable the company to access employee information quickly and effectively.

- Compiling a proper policy document that is aligned with all the other structures, processes and procedures in the organisation.

- Developing an effective multimedia communication system to keep employees informed on a regular basis.

- Assisting both the employees and management to have an effective up-to-date electronic HR manual in place aligned with other relevant policies and procedures.

- Developing a high degree of trust between the parties.

- Installing a number of web-based tools that will allow more frequent interaction with employees in remote areas.

- $\quad$ Training all managers in their responsibilities.

- Establishing a formal process whereby employees can apply to participate in the scheme and also make provision for an arbitration process should a manager not approve an individual request.

- Monitoring the benefits gained regularly and also identifying possible problems with the system.

According to Paton \& McCalman (2008:118), three basic implementation strategies are available: pilot studies, where a small group of staff are involved in implementation and parallel running, where the new system is phased in and the old one is slowly phased out, or a big bang approach, where the total system is implemented as soon as possible.

It is important to note that old systems and practices die hard and that it will take time for new systems to be fully accepted. However, good communication and proper support to those affected will contribute to the ultimate success of the project. It is vital that management should also be willing to terminate the plan, should it fail to meet its goals. The issue could also be referred back to the definition phase, as indicated in figure I.

\section{- $\quad$ Feedback}

As indicated previously, the model makes provision for feedback between the definition, evaluation and implementation phase. This is necessary should problems arise during any of these steps, such as the availability of sufficient time to train staff. If this is not possible, a return to the definition phase would be required. 


\section{- Problem conclusion}

Once the change process has been implemented, the project team could be dissolved.

\section{- Environmental development loop}

The last component of the model consists of an environmental development feedback loop linking the final outcome and the new environment with the initial situation. The purpose of this loop is to illustrate that the change cycle is never complete. As a result of the dynamic environmental factors that have developed over time it will become necessary for new changes to be made to the existing FWP package and the process will start again.

\section{Research design}

\section{Research approach}

In order to achieve the best results from this research, a quantitative descriptive research approach was adopted. Descriptive research provides a complete and accurate picture of the situation, whereas quantitative data can be used to describe the situation in terms of frequencies, central tendencies and dispersion (Struwig \& Stead, 2001:7-8). The advantages of this approach are that it saves time and money, gets accurate results, ensures confidentiality for individual respondents and does not require very large samples (Anderson, 2004:201-233).

\section{Research strategy}

The research was conducted in the South African context, specifically among companies listed on the Johannesburg Stock Exchange (JSE Limited). Three industries are represented, namely telecommunications (comprising wireless telecommunication and fixed-line telecommunication services), finance (comprising banks, investment instruments, real estate, life insurance and general insurance), and technology (comprising software and computer services and information technology hardware). These companies were identified from the official list of companies from the JSE website at http://www.jse.co.za. The researchers decided to approach the companies in these sectors as they are important building blocks of a country's growth, as indicated earlier. The listed companies also play a major role in determining the future direction these sectors will take in South Africa.

\section{Participants and sample}

As mentioned earlier, the population for this survey consisted of all the companies listed on the JSE in the three sectors, telecommunications, finance and technology, during April 2009. The number of listed companies in the three sectors were 4 (telecommunications companies), 84 (finance companies) and 17 (technology companies).

The total population consisted of 105 companies. However, the population had to be adjusted to 85 companies for the following reasons: A number of companies are holding companies with no more than four staff members; some of the companies had been suspended from the JSE; and a large number of companies indicated from the outset that they did not wish to participate. As explained above, the final population was 4 companies in telecommunications, 64 companies in the financial sector and 17 companies in technology.

The data were collected by means of a questionnaire. The HR Directors of the companies were contacted by telephone and informed about the survey. If they had no objection to participating, a questionnaire was sent to them via email for completion which they could return either by email or by post. A total of 25 usable questionnaires were returned, representing a response rate of $29,4 \%$. The returned questionnaires came from telecommunications (4 questionnaires), finance (16 questionnaires) and technology (5 questionnaires). For the purposes of this exploratory pilot study, the responses can be deemed to be representative of these three sectors on the JSE.

In Table 4, some demographic information pertaining to the sample is given. From this table it is clear that the majority of the respondents are senior HR leaders (Group Human Resource Managers) at their companies and as such are in a position to influence decisions pertaining to HR issues such as the use of FWP.

The companies are also major employers, with $52 \%$ of them employing between 1001 and over 7500 employees. They are also relatively old companies, with $96 \%$ of them between 10 and 100 years old, and they should therefore have well-established HR systems and processes (Withers, Williamson \& Reddington, 2010:65-67). Their assets and turnover are also significant and they can therefore be seen as major players in the South African economy. Most of the companies $(75 \%)$ are also in the maturity/diversification phase of development. In other words, they are well established in terms of their market share (Kleiman, 2009:911). However, the markets in which they operate are highly competitive ( $84 \%$ of the companies), while the pace of technological change relating to their products/services is changing very rapidly. In these circumstances only the best HR practices would suffice (Kleiman, 2009:11). The majority of the companies have relatively flat structures, with few layers of management, but $20 \%$ of the companies have an unconventional structure such as a matrix structure. Only $28 \%$ of the companies have a relatively tall structure with many layers of management.

\section{Measuring instrument}

After an intensive literature review, a questionnaire was compiled. The questionnaire consisted of the following sections:

- Section A: Background information relating to the company and respondent

- Section B: Use of technology in human resource management practices

- $\quad$ Section C: Flexible work practices (with subsections pertaining to type of practices, potential advantages, potential disadvantages, present barriers and possible solutions) A four-point Likert scale was used in Section $\mathrm{C}$ of the questionnaire. 
Table 4: Demographic information of the sample companies $(\mathrm{N}=\mathbf{2 5})$

\section{- $\quad$ Position of respondent}

(72\%) of the respondents are senior human resource managers in their respective organisations

\section{- $\quad$ Number of employees}

Small companies $\quad(<1000$ employees $)=12$ companies $(48 \%)$

Medium companies (between 1001 and 7500 employees) $=6$ companies $(24 \%)$

$\begin{array}{lll}\text { Large companies } & (>7501 \text { employees }) & =7 \text { companies }(28 \%)\end{array}$

- $\quad$ Age of the company

1 company $(4 \%) \quad<$ five years old

21 companies $(84 \%) \quad$ between 10 years and 49 years old

3 companies $(12 \%) \quad>75$ years old

- $\quad$ Annual turnover

$76 \%$ of the companies had a turnover of between R200 million to more than R1 000 million

$14 \%$ of the companies had a turnover of between R25 million and R100 million

$4 \%$ of the companies had a turnover of between R5 million and R10 million

$4 \%$ of the companies had a turnover of between R2 5 million and R5 5 million

$16 \%$ of the companies did not indicate their annual turnover

\section{- $\quad$ Approximate value of the total assets}

$73 \%$ of the companies had assets of between R200 million to more than R1 000 million

$26 \%$ of the companies had assets of between R25 million and R100 million

$8 \%$ of the companies did not indicate their approximate value of total assets

$\underline{\text { Stage of development of the company }}$

$75 \%$ of the companies are already in the maturity and diversification phase of development

$25 \%$ of the companies are in the growth phase

$4 \%$ of the companies did not indicate their stage of development

\section{- $\quad$ Nature of competition in the markets in which the companies operate}

$84 \%$ of the companies operated in highly competitive market

$12 \%$ of the companies operated in moderately competitive markets

$4 \%$ of the companies operated in a low degree of competition

\section{- $\quad$ Pace of technological change in companies}

$76 \%$ of the companies indicated that the pace of technological change is rapid/very rapid

$24 \%$ of the companies indicated that the pace of technological change is moderate $4 \%$ of the companies did not indicated markets with minimal competition

\section{- $\quad$ Company structure}

$52 \%$ of the companies have a relatively flat structure with few layers of management $28 \%$ of the companies have a relatively tall structure with many layers of management $20 \%$ of the companies have an unconventional structure (e g a matrix structure)

The researchers opted to use a questionnaire for this survey because they considered it financially more viable and quicker to administer. There are no interviewer effects and no interviewer variable and it was convenient for the respondents (Bryman \& Bell, 2003:142).

In this survey no formal pretest was conducted but inputs were obtained from staff in a human resource management department at one of the largest universities in South Africa. It was decided to follow this approach as the staff are specialists in the different areas covered in the questionnaire.

\section{Statistical analysis}

The data were analysed by means of a statistical package called SPSS (SPSS INC, 2003). Firstly descriptive statistics such as frequency distributions were generated to be used in sections A and B of the questionnaire. Secondly, owing to the small sample size and ordinal scale data, non-parametric tests (Kruskal-Wallis) were performed to test for significant differences between groups as defined by the corpographical variables. Significant levels of 0.05 and 0.10 (5\% and 10\%) were used. The binomial test, a test that determines whether the proportion of responses in two groups differ statistically significantly from 0.5 , was used to determine whether the respondents perceived specified aspects to be a significant advantage, disadvantage, barrier or solution in the subquestions contained in question 24 .

\section{Results and discussion}

\section{Business practices followed in the companies}

In Table 5, the business practices of the companies participating in the study are indicated. It appears that the use of formal strategic planning activities, with a written mission statement, business unit strategy and HRM strategy, is fairly prevalent in the companies.

\section{Table 5: Business practices of the sample companies ( $N$} = 25)

\section{- $\quad$ Use of formal strategic planning activities in companies}

$56 \%$ of companies made a great deal of use of formal strategic planning activities $32 \%$ of the companies made to some extent use of formal strategic planning activities $12 \%$ of the companies made to a minor extent use of formal strategic planning activities

\section{- $\quad$ Decision making power is centralised}

$56 \%$ of companies have to some extent centralised decision-making power $36 \%$ of companies have to a great extent centralised decision-making power $8 \%$ of companies have to a minor extent centralised decision-making power

\section{- $\quad$ HR's role in strategic decision-making}

$56 \%$ of companies indicated that their HR professional was not part of the team responsible for strategic decision-making

$44 \%$ of companies indicated that their HR professional was part of the team tasked with strategic decision-making

\section{- Mission statement}

$87 \%$ of companies had a written mission statement

$4 \%$ of companies had an unwritten statement

$4 \%$ of companies had no statement at all

$4 \%$ of the companies did not indicate

\section{- $\quad$ Business unit strategy}

$87 \%$ of companies had a written business unit strategy $8 \%$ of companies had an unwritten business unit strategy $4 \%$ of companies had no business unit strategy at all

\section{- $\quad$ HRM strategy}

$66 \%$ of companies had a written HRM strategy $20 \%$ of companies had an unwritten strategy $12 \%$ of companies had no strategy at all

- $\quad$ Stage which the HR person is involved in the development of the business unit strategy

In $44 \%$ of the companies HR professionals are involved from the very outset in the development of the business unit strategy for the company

In $24 \%$ of the companies HR professionals are only involved through subsequent consultation

In $16 \%$ of the companies HR professionals are involved at the implementation stage only

In $16 \%$ of the companies HR professionals are not consulted at all 
This is a significant finding as success is not possible without proper strategic planning, leading to a proper mission statement, business unit strategy and HRM strategy (Kleiman, 2009:62-64). It is also important to note that decision-making power in the companies is minimally centralised, which is also in line with modern business thinking (Withers et al., 2010:141). However, what is worrying is the fact that in the case of the majority of the companies, their HR professionals are not part of the team responsible for strategic decision-making at corporate level. Although the HR professionals are not directly involved, it is possible for them to provide the relevant HR information to the team beforehand, to be utilised during their discussions. However, the direct involvement of the HR professional at this level would be more acceptable and influential, especially when proposing new systems such as FWP (Kleiman, 2009:7-10). On a positive note, it was found that in most cases the HR professionals are involved from the very outset in the development of the business unit strategy for the company. This type of involvement enables companies to design realistic strategic plans for the future that take the people element into account. In other words, it will be possible to implement the business unit strategy from a people perspective (Kleiman, 2009:3).

\section{HRM technology}

The importance of the role played by technology in the management of organisations cannot be underestimated (Butler, 2000: 38-40). Although a late arrival in this area, computers have become an invaluable part of the daily operations of the HR Department. They are known by the acronym HRIS - Human Resource Information Systems (Tansley \& Newell, 2007:95). An HRIS is a computerised information package that provides HR management with an increasing capacity to record, store, manipulate and communicate information across a wide geographic area, allowing access to many users (Kavanagh \& Thite, 2009: 18-23). An HRIS contains information about a company's jobs and employees. The job file typically lists the number and types of jobs needed to achieve the organisation's strategic goals, while the employee file lists information such as the appointment date of the employee, salary history, performance ratings and training undertaken (PeopleSoft, 2000: 2-16). A company's HR professionals are usually responsible for gathering information and inputting it into the HRIS, as well as maintaining the system. For the FWP programme to work successfully, it is important that such an HRIS is available within the company to enable the HR professional to do the following (Offstein \& Morwick, 2009: XV):

- $\quad$ Be able to easily identify those jobs that can be part of the FWP programme.

- Make amendments to the content of the jobs participating in the programme, where the execution of certain job activities under the programme will no longer be possible.

- Establish clear goals for each job, especially where employees are sharing a job.
- Develop staffing schedules to ensure that there are adequate staff available in the company at all times.

- Monitor the hours worked, especially under the following FWP options: flexitime, compressed work weeks, overtime and shift work.

- Make new compensation structures available for each option in the FWP programme.

- Place sufficient information on the HRIS to assist managers and employees to learn more about the following: how to become a participant on the programme, how to manage staff working under one of the FWP options, how to find out what training is required before working under any of the options, and how to appeal to the company should an application to become a participant be rejected or withdrawn.

A number of aspects relating to a company's HRIS are dealt with in Section B of the questionnaire. The results indicate that the majority of companies (52\%) have a primary independent HR information system. However, a further $32 \%$ of the companies have an HR information system that is integrated into the wider management information system (MIS) of the company. This last group of companies are therefore in a favourable position to make informed business decisions when required. Only $16 \%$ of the companies indicated that they do not have a computerised HR information system. It is interesting to note that $15 \%$ of the companies use their HRIS at the first level of development, namely for information publishing purposes only, while $42 \%$ of the companies use it at a secondary level, namely to allow employees to gain access to some personal information, such as leave credits, pension and medical benefits and training done. A further $42 \%$ of the companies use it at the third level, namely allowing employees to perform complex transactions and select items (such as the composition of benefits) that can be calculated by the system. Unfortunately, six companies did not answer this question. From the items listed in this question, it appears that the most popular use of the HR information system by companies is in the area of payroll (100\% of the companies), followed by individual personnel records $(90 \%)$, benefits $(85 \%)$, training $(75 \%)$, time registration and attendance and performance management $(61 \%)$, recruitment and selection (58\%), career planning - succession planning and work scheduling (33\%), and lastly, health and safety (20\%). Overall it would appear that most of the HR activities on the HRIS of companies are fairly well, if not fully developed. This is a positive finding with regard to the management of their workforces. It is also a good foundation for the successful implementation of FWP. However, it appears that only $16 \%$ of the companies find that their HRIS largely meets their current needs; $54 \%$ of the companies indicate that their HRIS only partly meets their current needs. In the case of $4 \%$ of the companies their current needs are only being met to a minor extent, and in the case of a further $4 \%$ of the companies, needs are not met at all. Three companies did not answer the question. It is clear from the findings that the present HRIS does not fully meet the current needs of the majority of companies. This finding is not surprising, as only $42 \%$ of the companies use their system at the third level of development at present. This aspect needs to be addressed. 


\section{Flexible work practices used by companies}

In the first part of Section $\mathrm{C}$ of the questionnaire, the respondents had to indicate what proportion of their staff currently utilise the different flexible working arrangements listed in their companies. The results are indicated in Table 6.

It appears from Table 6 that the practice used by the largest number of companies (95\%) was overtime. This is not surprising because this practice has been in use globally for many years (Lepak \& Gowan, 2010:128-129). After overtime, the following are the most frequently used practices (in order of popularity, that is percentage of companies using them): fixed-term contracts (91\% of companies), flexitime (90\% of the companies), temporary/casual work ( $86 \%$ of companies), weekend work (63\% of companies), shift work (56\% of companies), parttime work ( $47 \%$ of companies), home-based work ( $45 \%$ of companies), teleworking and compressed working week (41\% of companies), annual hours ( $25 \%$ of companies), and lastly, job sharing ( $4 \%$ of companies). Despite the large number of companies utilising the different types of FWP, one should note that few companies actually have more than $20 \%$ of their staff participating in any particular option. Only in the case of annual hours and flexitime does the usage appear to be relatively greater. It would therefore appear that on average the focus is on less than $20 \%$ of the staff, which could possibly indicate favouritism. Thus, with the exception of annual hours and flexitime, very few companies have more than $20 \%$ of their staff utilising FWP practices at present, and this could impact negatively on issues such as productivity, morale, absenteeism and staff turnover, as mentioned earlier in this article (see Table 2).

\section{Kruskal-Wallis test for corpographic variables and the different flexible work practices used $(\mathrm{N}=25)$}

The responses of companies to the extent of usage of flexible work practices were recorded. These responses fell into two groups, namely those where usage was less than $20 \%$ and those where it was more than $20 \%$. This was done for the following two reasons:

1. The small sample size in each original response category

2. This provided a view on the non-use or limited use of flexible work practices as opposed to the moderate to high usage.

In order to determine if the medians for each flexible work practice differed statistically significantly between the groups as defined by the corpographical variables, for example the level of existence of business strategies (question 15) and the level of competition (question 8), Kruskal-Wallis tests were conducted. The Kruskal-Wallis test can determine, among other things, whether a significant difference exists between the medians of the shift work percentage for the different employment number groups as defined in question 2 of the survey - in other words, the pattern of responses for shift work would differ among different employee groups. The results of these tests appear in Table 7.

It is clear from Table 7 that, regarding the number of employees an organisation has, significant differences were found at the $10 \%$ level in two types of FWP used, namely shift work and compressed work week. This indicates that the extent to which these practices are employed by organisations differs significantly, depending on whether their staff is small, medium or large. This is understandable as both these practices can only be used if staff numbers are sufficiently high at the companies. Thus, larger companies would be more inclined to use these practices than smaller or medium-sized companies. Significant differences at the $5 \%$ level were also found in respect of the nature of competition companies experienced with reference to the following FWP, namely overtime used, flexitime, temporary/casual work, and fixed-term contracts. This finding is not surprising, as more innovative methods will be used by companies, depending on the type of competition they are encountering in the market. There also appears to be a significant difference at the $5 \%$ level with regard to the use of a formal strategic planning process within companies as far as the following FWP are concerned: annual hours contracts, job-sharing and telework. This is also understandable because when one plans formally for the future specific problems in the functioning of the company will be envisaged and then specific interventions such as annual hours contracts/teleworking and job-sharing might be necessary. If there is no formal planning, there may be no strategy for dealing with these issues when they crop up in future. Regarding the type of corporate level strategy pursued, a significant difference at the $5 \%$ level also showed up, for example:

- In the case of the overall cost leadership strategy (where companies aim to become the lowest cost producer in the industry), shift work and overtime were significant. This is not surprising as both practices have a direct impact on costs.

- In the case of a differentiation strategy (where companies aim to create a unique product or service), overtime, flexitime, temporary/casual work, fixedterm contracts and home-based work were significant. Again, all these FWP can play a very important role in putting this strategy into practice.

- In the case of the focus strategy (where companies cater for a specialised segment of the market such as a certain kind of customer), overtime, job-sharing, flexitime, temporary/casual work and fixed-term contracts were all identified again - they can all play an important part in putting the strategy into practice. 
Table 6: Flexible work practices used by the companies listed on the JSE

\begin{tabular}{|c|c|c|c|c|c|c|c|c|}
\hline \multirow[t]{2}{*}{ Flexible Work Practices } & \multicolumn{6}{|c|}{$\%$ of employees using this practice } & \multirow{2}{*}{$\begin{array}{l}\% \text { of } \\
\text { companies } \\
\text { using this } \\
\text { practice }\end{array}$} & \multirow[t]{2}{*}{ Missing \% } \\
\hline & Not used & $0-5 \%$ & $6-10 \%$ & $11-20 \%$ & $\begin{array}{l}\text { 21- } \\
\mathbf{5 0 \%}\end{array}$ & $>\mathbf{5 0 \%}$ & & \\
\hline $\begin{array}{lcc}\text { A } & \text { Weekend work } & \text { (working } \\
\text { Saturday and/or Sunday) } & \end{array}$ & $34 \%$ & $39 \%$ & $8 \%$ & $8 \%$ & $0 \%$ & $8 \%$ & $63 \%$ & $3 \%$ \\
\hline $\begin{array}{l}\text { B Shift work (working blocks of } \\
\text { hours which include time outside } \\
\text { normal working hours) }\end{array}$ & $41 \%$ & $20 \%$ & $16 \%$ & $12 \%$ & $0 \%$ & $8 \%$ & $56 \%$ & $3 \%$ \\
\hline $\begin{array}{l}\text { C Overtime (extra time beyond } \\
\text { employees' normal time, added on } \\
\text { to a day or shift) }\end{array}$ & $4 \%$ & $25 \%$ & $29 \%$ & $25 \%$ & $8 \%$ & $8 \%$ & $95 \%$ & $1 \%$ \\
\hline $\begin{array}{l}\text { D Annual hours contract } \\
\text { (agreement to work number of } \\
\text { hours annually) }\end{array}$ & $73 \%$ & $4 \%$ & $0 \%$ & $0 \%$ & $0 \%$ & $21 \%$ & $25 \%$ & $2 \%$ \\
\hline $\begin{array}{l}\text { E Part-time work (hours of work } \\
\text { defined as part-time by employer or } \\
\text { legislation) }\end{array}$ & $52 \%$ & $30 \%$ & $13 \%$ & $0 \%$ & $4 \%$ & $0 \%$ & $47 \%$ & $1 \%$ \\
\hline $\begin{array}{l}\text { F Job sharing (dividing up one job } \\
\text { between two or more employees) }\end{array}$ & $95 \%$ & $0 \%$ & $4 \%$ & $0 \%$ & $0 \%$ & $0 \%$ & $4 \%$ & $1 \%$ \\
\hline $\begin{array}{l}\text { G Flexitime (some working hours } \\
\text { may be determined by employees, } \\
\text { around a fixed "core" time) }\end{array}$ & $8 \%$ & $37 \%$ & $4 \%$ & $20 \%$ & $4 \%$ & $25 \%$ & $90 \%$ & $2 \%$ \\
\hline $\begin{array}{l}\text { H Temporary/casual (workers } \\
\text { employed on a temporary basis for a } \\
\text { number of hours, weeks or months) }\end{array}$ & $12 \%$ & $45 \%$ & $25 \%$ & $12 \%$ & $4 \%$ & $0 \%$ & $86 \%$ & $2 \%$ \\
\hline $\begin{array}{l}\text { I Fixed-term contracts (workers } \\
\text { employed for a fixed number of } \\
\text { months or years) }\end{array}$ & $8 \%$ & $54 \%$ & $8 \%$ & $25 \%$ & $4 \%$ & $0 \%$ & $91 \%$ & $1 \%$ \\
\hline $\begin{array}{l}\text { J Home-based work (workers } \\
\text { whose normal workplace is home } \\
\text { but who do not have permanent } \\
\text { electronic links to a fixed } \\
\text { workplace) }\end{array}$ & $54 \%$ & $37 \%$ & $4 \%$ & $0 \%$ & $4 \%$ & $0 \%$ & $45 \%$ & $1 \%$ \\
\hline $\begin{array}{l}\text { K Teleworking (technology based) } \\
\text { (workers who can link } \\
\text { electronically to a fixed workplace) }\end{array}$ & $58 \%$ & $25 \%$ & $4 \%$ & $0 \%$ & $8 \%$ & $4 \%$ & $41 \%$ & $1 \%$ \\
\hline $\begin{array}{l}\text { L Compressed working week } \\
\text { (workers whose working week } \\
\text { totals a standard number of hours } \\
\text { compressed into a reduced number } \\
\text { of shifts) }\end{array}$ & 58 & $33 \%$ & $8 \%$ & $0 \%$ & $0 \%$ & $0 \%$ & $41 \%$ & $1 \%$ \\
\hline
\end{tabular}


Table 7: Kruskal-Wallis tests: Corpographic variables and the different flexible work practices used (N=25)

\begin{tabular}{|c|c|c|c|c|c|}
\hline GROUPING VARIABLE & $\begin{array}{c}\text { FLEXIBLE WORK } \\
\text { PRACTICES }\end{array}$ & $\begin{array}{c}\text { CHI- } \\
\text { SQUARE }\end{array}$ & DF. & P -VALUE & $\begin{array}{c}\text { SIGNIFICANCE } \\
\text { LEVEL }\end{array}$ \\
\hline \multirow[t]{2}{*}{ Number of Employees } & Shift work & 15.4429 & 9 & 0.0795 & $10 \%$ level \\
\hline & Compressed working week & 16.4286 & 9 & 0.0585 & $10 \%$ level \\
\hline \multirow[t]{4}{*}{ Nature of Competition in Market } & Overtime & 23.0 & 2 & 0.00 & $5 \%$ level \\
\hline & Flexitime & 11.0818 & 2 & 0.0039 & $5 \%$ level \\
\hline & Temporary & 7.2286 & 2 & 0.0269 & $5 \%$ level \\
\hline & Fixed-term contracts & 14.6364 & 2 & 0.0007 & $5 \%$ level \\
\hline \multirow[t]{3}{*}{ Formal Strategic Planning Usage } & Annual hours contract & 4.9916 & 2 & 0.0824 & $10 \%$ level \\
\hline & Job sharing & 7.00 & 2 & 0.0302 & $5 \%$ level \\
\hline & Teleworking & 6.102 & 2 & 0.0473 & $5 \%$ level \\
\hline \multirow{2}{*}{$\begin{array}{l}\text { Overall Cost Leadership Usage } \\
\text { Level }\end{array}$} & Shift work & 6.6909 & 2 & 0.0352 & $5 \%$ level \\
\hline & Overtime & 7.00 & 2 & 0.0302 & $5 \%$ level \\
\hline \multirow[t]{5}{*}{ Differentiation Usage Level } & Overtime & 23.00 & 3 & 0.00 & $5 \%$ level \\
\hline & Flexitime & 11.3506 & 3 & 0.0100 & $5 \%$ level \\
\hline & Temporary & 7.9796 & 3 & 0.0464 & $5 \%$ level \\
\hline & Fixed-term contracts & 11.3506 & 3 & 0.0100 & $5 \%$ level \\
\hline & Home based work & 6.4565 & 3 & 0.0914 & $10 \%$ level \\
\hline \multirow[t]{5}{*}{ Focus Usage Level } & Overtime & 22.00 & 3 & 0.0001 & $5 \%$ level \\
\hline & Job sharing & 6.6667 & 3 & 0.0833 & $10 \%$ level \\
\hline & Flexitime & 10.8129 & 3 & 0.0128 & $5 \%$ level \\
\hline & Temporary & 7.5429 & 3 & 0.0565 & $10 \%$ level \\
\hline & Fixed-term contracts & 10.8129 & 3 & 0.0128 & $5 \%$ level \\
\hline Mission Statement Existence & Fixed-term contracts & 10.5548 & 3 & 0.0144 & $5 \%$ level \\
\hline Business Strategy Existence & Job Sharing & 10.50 & 2 & 0.0052 & $5 \%$ level \\
\hline \multirow[t]{2}{*}{ HRM Strategy Existence } & Overtime & 6.6667 & 2 & 0.0357 & $5 \%$ level \\
\hline & Fixed-term contracts & 13.9683 & 2 & 0.0009 & $5 \%$ level \\
\hline
\end{tabular}

A mission statement normally contains a section where a company makes a commitment regarding the utilisation of its staff. Here, too, significant differences were found at the $5 \%$ level with regard to fixed-term contracts. Thus, depending on the type of mission statement, namely written, unwritten or not used, the commitment to the use of fixedterm contracts will differ. There is also a significant difference at the 5\% level with regard to the existence of a business unit strategy as far as job-sharing is concerned. Again, depending on the type of strategy (namely, written, unwritten and not used) the use of job-sharing will differ. The same applies to the HRM strategy within a company here a significant difference was also found at the 5\% level. Two FWP were significant here, namely overtime and fixedterm contracts. These practices can play an important role in the implementation of the HRM strategy in the case of a written strategy but this may not be the case with an unwritten HRM strategy.

To summarise, it is clear that the use of FWP is influenced by a number of corpographic variables in the present study, such as staff numbers.
Binomial test: Perceptions of respondents regarding the advantages, disadvantages, barriers and solutions when using or considering using flexible work practices

In the second part of Section $\mathrm{C}$ of the questionnaire, the respondents had to indicate their perceptions of the advantages, disadvantages, barriers and solutions when using or considering using flexible work practices. Two groups were distinguished here, namely Group 1, which contained the responses "to no extent "and "to a minor extent "and Group 2, which contained the responses "to some extent "and "to a great extent".

The binomial test indicates whether the respondents perceived an aspect to be a significant advantage, disadvantage, barrier or solution. Thus, the test determines whether the proportion of responses in the two groups differs statistically significantly from 0.5 .

\section{- Advantages}

Effective time utilisation, increase in productivity, balance of work and family life and an increase in job satisfaction have all been perceived as advantages where the proportion of responses in the two groups differ statistically significantly. The proportion of Group 2 responses (see 
Table 8) indicates that these advantages are seen as positive by the majority of respondents. This is in line with the views of other studies published in the literature (Meisinger, 2007:12; Harris, 2007:33; Döckel et al., 2006:20-22; Sandler, 2008: 10-11; Wilson, 2007 :1; Roberts, 2005:1; Kettleborough, 2009: 6; Shyrme, 2002:1-4; O'Brien \& Hayden, 2008:19; Stredwick \& Ellis, 2008: 30).

What is interesting, however, is that cost savings were not seen as a significant positive advantage by the respondents. This is somewhat strange, as it contradicts the findings reported in the literature (Ministry of Manpower. Singapore, 2001:1-23). For example, where employees work under the Teleworking/Telecommuting system, they do not require permanent offices as they work either from home or at other locations away from the office - thus saving office space. Perhaps the low usage of this system by companies in the survey, as well as the small number of employees participating in this FWP at the moment (see Table 6), are the reason for this view. They have not discovered the true benefits at this stage.

\section{- Disadvantages}

The potential disadvantage "flexible work practices threat to job security" listed in the questionnaire has been perceived as a disadvantage where the proportion of responses in the two groups differ statistically significantly. However, as the proportion of Group 1 responses (see Table 9) indicates, this disadvantage is the only one which the majority of respondents did not perceive to be a possible disadvantage. Thus, the respondents did not identify any significant disadvantages when implementing or thinking of implementing FWP.

This is a very positive finding and indicates the companies' sophistication from a business perspective, as confirmed in the World Competitiveness Report -see paragraph 2.0 earlier.

\section{Present barriers}

The present barriers "access to technology and IT support" and "cost of custom-altered technology" were perceived as barriers where the proportion of responses in the two groups differs statistically significantly. However, the proportion of Group 1 responses (see Table 10) indicates that these barriers are not perceived to be true barriers any longer.

Thus, the respondents did not see any true barriers when implementing or considering implementing FWP. This could be largely due to the advances and cost reductions in information and telecommunication technologies. This finding correlated with South Africa's ranking in the World Competitiveness Report in these areas - see paragraph 2.0 earlier.

\section{- Possible solutions}

The possible solutions as indicated in Table 11 have all been perceived as possible solutions where the proportion of responses in the two groups differs statistically significantly. The proportion of Group 2 responses as indicated in the table indicates that these possible solutions have been seen as definite solutions by the majority of respondents. This finding supports the views found in the literature (Kettleborough, 2009: 6; Stavrou, Spiliotis \& Charalambous, 2010:893-902).

To summarise, the respondents did not perceive any serious disadvantages or barriers when implementing or thinking of implementing FWP. The respondents did, however identify a number of advantages and solutions when implementing or thinking of implementing FWP which are in line with findings published in the literature.

Table 8: Potential advantages of using FWP

\begin{tabular}{lllc}
\hline $\begin{array}{l}\text { POTENTIAL } \\
\text { ADVANTAGES }\end{array}$ & OBSERVED PROPORTION & P-VALUE & SIGNIFICANCE LEVEL \\
\hline Effective time utilisation & $\begin{array}{l}\text { Group } 1=0.22 \\
\text { Group 2 }=0.88\end{array}$ & $\mathrm{p}=.0002$ & $5 \%$ level \\
\hline Increase in productivity & $\begin{array}{l}\text { Group } 1=0.08 \\
\text { Group 2 }=0.92\end{array}$ & $\mathrm{p}=.0000$ & $5 \%$ level \\
\hline $\begin{array}{l}\text { Balance work and family } \\
\text { life }\end{array}$ & $\begin{array}{l}\text { Group 1 }=0.22 \\
\text { Group 2 }=0.88\end{array}$ & $\mathrm{p}=.0002$ & $5 \%$ level \\
\hline Increase in job satisfaction & Group 1 $=0.08$ & $\mathrm{p}=.0000$ & $5 \%$ level \\
& Group 2 $=0.92$ & & \\
\hline
\end{tabular}

Table 9: Potential disadvantages when implementing or thinking of implementing FWP

\begin{tabular}{llll}
\hline POTENTIAL & OBSERVED PROPORTION & P-VALUE & SIGNIFICANCE LEVEL \\
DISADVANTAGES & & $\mathrm{p}=.0001$ & $5 \%$ level \\
\hline $\begin{array}{l}\text { Flexible work practices threat } \\
\text { to job security }\end{array}$ & $\begin{array}{l}\text { Group } 1=0.913 \\
\text { Group } 2=0.087\end{array}$ & & \\
\hline
\end{tabular}

Table 10: Possible barriers to considering/implementing FWP

\begin{tabular}{llll}
\hline BARRIERS & OBSERVED PROPORTION & P-VALUE & SIGNIFICANCE LEVEL \\
\hline $\begin{array}{l}\text { Access to technology \& IT } \\
\text { support }\end{array}$ & Group 1 $=0.85$ & $\mathrm{p}=.0015$ & $5 \%$ level \\
\hline $\begin{array}{l}\text { Cost of custom- altered } \\
\text { technology }\end{array}$ & Group 2 $=0.15$ & & $5 \%$ level \\
\hline
\end{tabular}


Table 11: Possible solutions for implementing FWP

\begin{tabular}{|c|c|c|c|}
\hline POSSIBLE SOLUTIONS & OBSERVED PROPORTION & P-VALUE & SIGNIFICANCE LEVEL \\
\hline $\begin{array}{l}\text { Clear criteria to determine } \\
\text { eligibility }\end{array}$ & $\begin{array}{l}\text { Group } 1=0.167 \\
\text { Group } 2=0.833\end{array}$ & $\mathrm{p}=0.0015$ & $5 \%$ level \\
\hline Proper control mechanism & $\begin{array}{l}\text { Group } 1=0.208 \\
\text { Group } 2=0.792\end{array}$ & $\mathrm{P}=0.0066$ & $5 \%$ level \\
\hline Involve all stakeholders & $\begin{array}{l}\text { Group } 1=0.167 \\
\text { Group } 2=0.833\end{array}$ & $\mathrm{p}=0.0015$ & $5 \%$ level \\
\hline $\begin{array}{l}\text { Expose management to training in } \\
\text { the area }\end{array}$ & $\begin{array}{l}\text { Group } 1=0.292 \\
\text { Group } 2=0.708\end{array}$ & $\mathrm{p}=0.0639$ & $10 \%$ level \\
\hline $\begin{array}{l}\text { Change in the nature of } \\
\text { employment practices wrt the } \\
\text { employment contracts of flexible } \\
\text { work teams }\end{array}$ & $\begin{array}{l}\text { Group } 1=0.304 \\
\text { Group } 2=0.696\end{array}$ & $\mathrm{p}=0.0931$ & $10 \%$ level \\
\hline $\begin{array}{l}\text { Develop a communication and } \\
\text { training strategy }\end{array}$ & $\begin{array}{l}\text { Group } 1=0.292 \\
\text { Group } 2=0.708\end{array}$ & $\mathrm{p}=0.0639$ & $10 \%$ level \\
\hline
\end{tabular}

\section{Recommendations}

On the basis of the findings, the following recommendations are made:

Companies in the telecommunications, financial and technology sectors in South Africa should do the following:

- Investigate the greater use of flexible work practices in their organisations, especially against the background of the benefits derived from this for the employer, the employee and the community at large.

- Obtain management support in the companies for the greater use of flexible work practices.

- Investigate the better integration of the human resource information systems(HRIS) with the company's management information system (MIS) and determine why the HRIS is not fully meeting the need at present.

- Empower the person responsible for HR issues at the company to become a true business partner. If this could be achieved, the true value of the HR contribution to the bottom line of the company would be realised.

- When implementing flexible work practices, companies should follow the guidelines recommended in section 5.6 of this article, without which the whole process is doomed to failure

Lastly, the South African government should investigate the possibility of making provision in labour legislation for the use of these practices in companies, as is currently being done in the United Kingdom under its Employment Act 2002 (as amended) (Croucher \& Kelliher, 2005:503520).This practice has led to a great deal of harmonisation in the workforce.

\section{Limitations of the study}

It is important to note that this study had a number of limitations. A major limitation of the current research, due mainly to the small sample used and the fact that the study only focused on three sectors of the economy, is that the findings cannot be generalised. However, given the limited amount of research conducted in South Africa in this area to date, the study does provide some insight into what is happening at present in these important sectors of the economy and as such, it does make a contribution to new knowledge in this field. Further studies with larger samples should be conducted and should also include other sectors of the economy. Issues where a deeper understanding is needed include the use of FWP by men and women, skilled versus unskilled employees, as well as whether these practices have any impact on the career progression of employees in organisations.

\section{Conclusion}

There is no doubt that there have been major changes in the world of work and those who work in it. Companies worldwide are often faced with three generations of employees (viz baby boomers, generation $X^{\prime}$ 's and generation $Y^{\prime}$ 's), each with their own particular set of demands (Brown, 2009:10).This situation requires changes not only in the business strategies of companies but also in the way their employees are managed. In many instances, innovative HR strategies are required to enable companies to remain competitive. In addition to these challenges, a serious shortage of skilled/talented workers has developed in the past decade, necessitating drastic measures by companies. It is evident from this research that to address these problems, companies are increasingly introducing the concept of flexible work practices in their organisations. According to a large number of studies published, numerous benefits can be derived from these practices, not only for the organisation, but also for the employees as well as the community at large, despite some challenges which also exist. For employees, flexible work practices can lead to higher productivity, increased morale, lower absenteeism and most importantly, lower turnover. South African 
companies should therefore take up the challenge immediately!

\section{References}

Anderson, V. 2004. Research methods in human resource management. London: Chartered Institute of Personnel and Development (CIPD).

Beeld (Sake). 12/6/2009. 'ArcelorMittal snoei salarisse', p.3.

Beeld Sake 24. 4/8/2009. 'Kundigheid exodus lei tot munisipale plae', p.12.

Bernardin, H.J. 2003. Human resource management: An experiential approach. Boston: McGraw-Hill/Irwin.

BNET business dictionary. [online] URL:http://dictionary.bnet.comldefinitionlflexible+working. html. Accessed on 24 June 2009.

Brown, A. 2009. 'Flexible work practices at Nedbank'. Paper presented on 24 June 2009 at the Talent Management Conference in Johannesburg.

Bryman, A. \& Bell, E. 2003. Business research methods. Oxford: Oxford University Press.

Butler, A.S. 2000. 'Developing your company's new ebusiness', Journal of Business Strategy, 21(6):38-40.

Cheese, P. 2008. 'Talent a prerequisite for high performance companies', Management Today, Mar:38-42.

Croucher, R. \& Kelliher, C. 2005. 'The right to request flexible working in Britain: The law and organisational realities of Comparative Labour Law and Industrial Relations', 21(3):503-520.

Davis, T., Cutt, M., Flynn, N., Mowl, P. \& Orme, S. 2007. Talent assessment: A new strategy for talent management. Aldershot, Hampshire: Gower.

Döckel, A., Basson, J.S. \& Coetzee, M. 2006. 'The effect of retention factors on organisational commitment: An investigation of high technology employees', South African Journal of Human Resource Management, 4(2):20-28.

Eigenhuis, A. \& Van Dijk, R. 2007. High performance business strategy. London: Kogan.

Esterhuizen, W. \& Martins, N. 2008. 'Organisational justice and employee responses to employment equity', South African Journal of Labour Relations 32(2):66-85.

Frase, M.J. 2007. 'Stocking your talent pool', HR Magazine, 52(4):67-74.

Gilmore, S. \& Williams, S. 2009. Human resource management. Oxford: Oxford University Press.

Galinsky, E., Bond, J.T. \& Hill, E.J. 2004. 'Status report on workplace flexibility: Who has it? Who wants it? What difference does it make?' London Chartered Institute of
Personnel and Development. (CIPD). [online] URL: http://familiesandwork.org/3w. Accessed on 24 June 2009.

Harris, P. 2007. 'Flexible work policies mean business', Training and Development, Apr:32-36.

Harris, M. 2009. 'Retrench, but keep you talent', Sunday Times/Careers, 26 Jul p.16.

Hloma, X. \& Ortlepp, K. 2006. 'People management implications of virtual workplace arrangements', Acta Commercii, 6:28-38.

Horgan, K.F. 2008. 'Creating flexible workplaces', Open Forum [online] URL: http://open forum.com.au. Accessed on 24 June 2009.

Jansen, W., Steenbakkers, W. \& Jägers, H. 2007. New business models for the knowledge economy. Aldershot, Hampshire: Gower.

Hunter, I., Saunders, J., Boroughs, A. \& Constance, S. 2006. HR business partners. Aldershot, Hampshire: Gower.

Kavanagh, M.J. \& Thite, M. 2009. Human resource information systems: Basic applications and future directions. Thousand Oaks, CA: Sage.

Kelliher, C. \& Anderson, D. 2008. 'For better or for worse? An analysis of how flexible work practices influence employees' perception of job quality', The International Journal for Human Resource Management, 19(3):419-431.

Kelly, E.L. \& Kalev, A. 2006. 'Managing flexible work arrangements in US organisations: Formalised discretion or a right to ask', Socio-Economic Review, 4(3): 379-416.

Ketchen, D.J. \& Berg, D.D. (eds.). 2007. Research methodology in strategy and management, vol 4. Oxford: JAI Press (an imprint of Elsevier).

Kettleborough, J. 2009. 'Strategies for cost effective flexible working'. CENTRA. [online] URL: http://www.centra.com. Accessed on 14 June 2009.

Kleiman, L.S. 2009. Human resource management: A managerial tool for competitive advantage. Mason, $\mathrm{OH}$ : Cengage Learning.

Knowledge Resources. 2009. One-day seminar on flexible work practices, 24 June, Bryanston, Johannesburg.

Kruskal-Wallis (See Casio, W.F. \& Aguinis, H. 2005. Applied psychology in human resource management. Upper Saddle River, New Jersey: Pearson/Prentice Hall.

Lepak. D. \& Gowan, M. 2010. Human resource management: Managing employees for competitive advantage. Upper Saddle River, NJ: Pearson Education.

Mackay, A. 2007. Motivation, ability and confidence building in people. Amsterdam \& Oxford: ButterworthHeinemann. 
Mathis, R.L. \& Jackson, J.H. 2003. Human resources management. $10^{\text {th }}$ Edition. Mason, OH: South-Western (a division of Thomson Learning).

Meisinger, S. 2007. 'Flexible schedules make powerful perks', HR Magazine, 52(4):12.

Ministry of Manpower. Singapore. 2001. Working paper: Flexible work arrangements, p.1-23. [online] URL: http://www.mom.gov.sa. Accessed on 18 June 2009.

Mullins, L.G. 2007. Management and organisational behaviour. $8^{\text {th }}$ Edition. Essex: Pearson Education.

O'Brien, T. \& Hayden, H. 2008. 'Flexible work practices and the IS sector: Balancing the needs of work and life?', Library Management 39(3):199-228.

Odendaal, A. \& Roodt, G. 2002. 'Australian and South African perspectives on the implementation of flexible work practices (FWP): An exploratory study', SA Journal of Industrial Psychology, 28(3):75-82.

Offstein, E.H. \& Morwick, J.M. 2009. Making telework work: Leading people and leveraging technology for highimpact results. Boston: Brealy :XV.

Paton, R.A. \& McCalman, J. 2008. Change management: A guide to effective implementation. $3^{\text {rd }}$ Edition. London: Sage: 108 .

PeopleSoft. 2002. Information brochure, p.2-16.

Price, A. 2004. Human resources management in a business context. $2^{\text {nd }}$ Edition. London:Thompson.

Ready, D.A. \& Conger, J.A. 2007. 'Talent factory', Harvard Business Review, 85(6):69-77.

Robert, M. \& Börjesson, M. 2006. 'Company incentives and tools for promoting telecommuting', Environment and Behaviour, 38(4): 521-549

Roberts, C. 2005. 'Flexible working', TES Magazine, 6 May. [online] URL:http://www/tes/co.uk. Accessed on 14 June 2009.

Rothwell, W.J., Prescott, R.K. \& Taylor, M.W. 2008. Human resource transformation. Mountain View, CA: Davies-Black.

Sandler, S.F. 2008. Flexible schedules get a boost from high gas prices. HR Focus 85(8):10-11.

Sandler, S.F. 2006. 'Retention, morale and productivity result from work/life programs', HR Focus, 83(8):S1-S4.

Sexton, C. 2008. 'Interim human resources management reasons to be flexible'. [online] URL: http:// ezinearticles.com. Accessed on 13 June 2009.

Shyrme, D.J. 2002. 'Flexible working: Reaping the benefits'. [online] URL: www.shyrme.com/pubs/fivreapin htm. Accessed on 10 June 2009.

SPSS Inc. 2003. SPSS12.0 for Windows. Chicago II.

Stavrou, E., Spiliotis, S. \& Charalambous, C. 2010. 'Flexible working arrangements in context: An empirical investigation through self-organising maps', European Journal of Operation Research, 202:893-902.

Stredwick, J. 2005. An introduction to human resource management. 2nd edition. Oxford: Elserivier ButterworthHeinemann.

Stredwick, J. \& Ellis, S. 2008. Flexible working. London: Chartered Institute of Personnel and Development (CIPD).

Struwig, F.W. \& Stead, G.B. 2001. Planning, design and reporting research. Cape Town: Maskew Miller Longman.

South Africa. The Presidency. 2008. Scenarios 2025. Booklet published by the Policy Co-ordination and Advisory Services (PCAS).

Sunday Times/Careers, 12/4/2009. 'Firms go flexible to retain key staff', p.16.

Taleo Corporation Research. 2008. 'White Paper: Talent management in a down economy'. [online] URL: info@taleo.com. Accessed on 7 June 2009.

Tansley, C. \& Newell, S. 2007. 'A knowledge-based view of agenda formation in the development of human resource information systems', Management learning 28(1): 95-119.

Wilson, B. 2007. 'Flexible working: Increased productivity'. [online] URL:http://arabianbusiness.com . Accessed on 28 May 2009.

World Economic Forum. 2009. World Competitiveness Report 2008/2009. Geneva: WEF.

Withers, M., Williamson, M. \& Reddington, M. 2010. Transforming HR: creating value through people. Oxford: Butterworth-Heinemann (an imprint of Elsevier). 